\title{
POSSIBLE BENEFITS OF THE FEDERAL TRADE COMMISSION
}

\author{
By Alexander W. Smith, \\ Counsellor at Law, Atlanta, Ga.
}

The obvious cause of the trust problem is the unlimited power to create corporations now lodged in the several states with no adequate power vested anywhere to control them.

In the days of isolation, trade was at first protected from restraint and commerce from monopoly, by prohibiting the primitive expedients of forestalling, regrating and engrossing. Experience soon demonstrated that such prohibition defeated its own object, and the old English acts were repealed (221 U. S. 55). But when the engrossing of "dead victual" grew to an international trust and combination, the ancient and discarded prohibitory measure was reënacted and crudely enlarged, in the form of the Sherman Anti-trust Act of 1890. After some twenty-five years of experimentation under it, to the great disturbance of business, a bill of particulars to the general inhibitions of the Sherman Act was supplied under the title of the Clayton Act of October, 1914.

During these twenty-five years of antagonism and estrangement between business and government, the means of intercommunication were augmented by the telephone, the wireless and the aeroplane, so that earth and sea and air are now joined together. Means of intercommunication measure the limits of trade, and when they become world-wide, commerce becomes universal. As the legislation on the subject embraced in the anti-trust acts was altogether restrictive, while the conditions underlying the commerce it sought to restrict were altogether expansive, it is not to be wondered at that things have been "at sixes and sevens" and the business men of the United States have come at last to be timid, irritated, anxious, and alarmed by reason of long combat with the deadliest of all enemies to business-Uncertainty.

The act of September, 1914, creating the Federal Trade Commission was and is doubtless considered solely an adjunct to the anti-trust acts. But it is more than a mere adjunct to the anti- 
trust acts. Let us see if a close inspection of the machinery which it creates will not develop possibilities of its use to correct the evils of the past, and transform antagonism into harmony, timidity into courage, alarm into security, irritation into coöperation, and uncertainty into knowledge.

This machinery is in process of finding itself; its bearings are being adjusted; its direction is being fixed; its power is being applied. If it may be so installed as to move in lines parallel with, rather than counter to, the trend of business development, the Federal Trade Commission will prove the greatest possible boon to business.

The saving salt of the Trade Commission Act is the limitation of complaints to the commission itself and restricting such complaints to matters injuriously affecting the public interest. What is the public interest? It is greater and wider, and deeper and broader, than any private interest or group of private interests. It is the sum total of all business and all government and all politics. It is civilization itself. It is made up of all the wonderful achievements of religion, and politics, and science, and art, and commerce, and industry, in the past, and anything which diminishes these accumulations, or endangers their legitimate increase for all the future, is injurious to the public interest.

Surely when gauged by this standard, the petty complaints, with which the commission will at first be bombarded by the disgruntled or disappointed or dishonest tradesman or groups of tradesmen, will be given short consideration and certain dismissal. Let it be understood, early and unmistakably, that the commission audience chamber is not to be the forum for airing the failures of the out-classed or out-of-date business man.

Competition in trade is warfare. In all civilized warfare there are certain rules of the game; but the great trouble is the absence of an umpire clothed with power to compel observance of them; and as a result retaliation is the only recourse. So in the matter of trade warfare, the great desideratum is to vest power somewhere to referee the contest. The Trade Commission Bill, rightly understood and conservatively enforced, will supply this need. Following up the analogy between trade competition and warfare, it may be said that the commission is well within the charter of its existence, and the capacity of its personnel, if it assumes the functions of a general staff of the great army of industry in this country. In that 
army-organization the Interstate Commerce Commission and the Federal Reserve Board might be termed bureaus in the quartermaster's and paymaster's departments. These boards should belong to the general staff along with the Trade Commission. A metropolitan daily recently said that eleven men constituting the majorities of these three bodies now have "nearly absolute power over affairs intimately concerning all trade on a national scale." "International scale" might well be substituted, as will appear later on.

The general staff's duties toward the armies under it, when not confronting the enemy, are largely disciplinary. Questions of sanitation and subsistence, of efficiency and good order, of equipment and protection, and the like, may well require and receive the best thought of the best minds. In dealing with them, however, they should be approached in a spirit of helpfulness and guidance, not of chastisement for errors perhaps unwittingly committed, followed by inscrutable silence as to the avoidance of similar mistakes thereafter.

The information and records which already exist, and which will be augmented by the investigations and reports required by the act, will enable the commission to issue "general orders" from time to time which will make it easy for this great army in all its divisions to adjust itself to the demands of the law for an open field and a fair fight, and the prophylaxis of publicity will make impossible any dangerous infection of the commercial body.

But the charter of the powers of this commission makes it far more than an adjunct to the anti-trust acts. Indeed it may be asserted that the anti-trust acts are but adjuncts to the Trade Commission in the exercise of its extraordinary powers. Having provided for the harmonious and efficient operation of our splendid industrial army at home, the real work of the general staff begins when the mighty energies of this great working force are directed against like forces in foreign lands. The act empowers the Trade Commission

to investigate, from time to time, trade conditions in and with foreign countries where associations, combinations, or practices of manufacturers, merchants, or traders, or other conditions, may affect the foreign trade of the United States, and to report to Congress therein, with such recommendations as it deems advisable.

To resume the simile: Let the general staff mass its brigades, and, if necessary, its army corps, to attack and capture the fields 
of commerce in South America, in China and elsewhere. With the wonderful resources of this great country fully developed and harmoniously operated under the beneficient guidance of the Trade Commission; with the coöperation of the Interstate Commerce Commission to allow differentials wherever necessary to promote foreign trade; with the aid of the Federal Reserve Board to furnish adequate banking facilities-our commercial invasion of foreign lands may be expected to demonstrate anew that, indeed,

"Peace hath her victories no less renowned than war." 